prof.dr hab. inz. Marek Sitarz

dr inż. Adam Mańka

dr inz. Andrzej Hetka

Politechnika Ślaska

\title{
Badania numeryczne i doświadczalne układu koło kolejowe - klocek hamulcowy
}

\begin{abstract}
W artykule przedstawiono wyniki prac Katedry Transportu Szynowego w zakresie badań doświadczalnych $w$ tym eksploatacyjnych i stanowiskowych oraz badań numerycznych elementów uktadu koło kolejowe - szyna oraz koło - klocek hamulcowy (KSK) czyli elementów, które maja szczególnie istotne znaczenie dla bezpieczeństwa $w$ transporcie szynowym. Ze względu na znacznq ilość badań zwiqzanych z uktadem KSK artykut ten poświęcono głównie zjawiskom naprężeń resztkowych wynikajacych $z$ intensywnego hamowania i nagrzewania powodujacego przekroczenie granicy plastyczności materiału koła kolejowego.
\end{abstract}

\section{Wstęp}

Ciągły rozwój transportu szynowego na świecie oraz zaostrzanie wymagań i obostrzeń prawnych związanych $\mathrm{z}$ ochroną środowiska oraz zapewnieniem bezpieczeństwa wymusza na producentach branży kolejowej stosowania nowych rozwiązań konstrukcyjnych oraz zmian $\mathrm{w}$ sposobie użytkowania $\mathrm{i}$ utrzymania elementów i pojazdów szynowych. Ciągłe dążenie do optymalizacji konstrukcji wynika również z konieczności zwiększania sprawności technicznej i redukcji masy elementów a przede wszystkim zwiększania ich efektywności ekonomicznej.

W świetle wymogów prawnych, większość elementów pojazdów szynowych oraz infrastruktury kolejowej wymaga przeprowadzenia stosownych badań dla potwierdzenia wymagań prawnych, normatywnych oraz specyficznych wymagań klienta dla zapewnienia bezpieczeństwa oraz funkcjonalności dopuszczanych do eksploatacji elementów. Badania te często są bardzo złożone i długotrwałe i obejmują próby stanowiskowe, $\mathrm{w}$ tym badania materiałowe oraz coraz częściej badania numeryczne (dla weryfikacji szczególnie niekorzystnych konfiguracji obciążeń), badania ruchowe oraz wielosezonowe badania eksploatacyjne. Dopiero pozytywne wyniki badań przeprowadzonych przez uprawnioną jednostkę są podstawą do ubiegania się przez wnioskującego o wydanie przez Urząd Transportu Szynowego świadectwa typu, które to zazwyczaj wydawane jest jako świadectwo terminowe.

W przypadku kół kolejowych jak i wstawek hamulcowych zakres badań dla uzyskania świadectwa typu jest szczególnie szeroki i uwzględnia również badania numeryczne dlatego też artykuł ten poświęcono głównie zjawiskom termicznym występującym w badanym układzie KSK.

\section{Wymagania normatywne dotyczące własności termomechanicznych}

Lista norm związanych ze wstawkami hamulcowymi, zarówno wykonanymi $\mathrm{z}$ żeliwa $\mathrm{P} 10$, jak $\mathrm{i}$ wstawkami kompozytowymi typu K i LL zajmuje prawie dwie strony, natomiast norm dotyczących wytwarzania, badania i eksploatacji kół kolejowych jest jeszcze dłuższa. Jednym $\mathrm{z}$ dokumentów, które przedstawiają wymagania dotyczące kół kolejkowych jest Dziennik Urzędowy Unii Europejskiej 2006/861/WE wraz z późniejszymi zmianami wprowadzonymi decyzją 2009/107/WE zawierający Decyzję Komisji z dnia 28 lipca 2006 r. dotyczącą technicznej specyfikacji dla interoperacyjności odnoszącej się do podsystemu ,tabor

kolejowy - wagony towarowe" transeuropejskiego systemu kolei konwencjonalnych, zwany potocznie TSI "Tabor - wagony towarowe" [1]. W dokumencie tym w szczegółowy sposób zawarto informacje i wytyczne dotyczące procedury badań dopuszczeniowych kół kolejowych dla spełnienia wymagań TSI.

$\mathrm{Na}$ uwage zasługuje w tym momencie fakt, że Dziennik Urzędowy Unii Europejskiej 2006/861/WE wraz z późniejszymi zmianami wprowadzonymi decyzją 2009/107/WE zawiera wyłącznie określenie "obręcz" i nie stosuje nazwy "wieniec" koła kolejowego. Jednocześnie norma PN-EN 13979, na której bazuje wspomniany dokument, dotyczy wyłącznie kół monoblokowych i używa nazwy "wheel rim". Wynika to zapewne $\mathrm{z}$ błędu $\mathrm{w}$ thumaczeniu jednak wprowadza pewną nieścisłość $\mathrm{w}$ interpretacji wymagań.

Wspomniany dokument TSI stawia konieczność przeprowadzenia prób stanowiskowych dla wszystkich kół kolejowych dopuszczanych do eksploatacji. 
Dla badań mających za zadanie weryfikację konstrukcji koła na obciążenia termomechaniczne przewidziano oprócz badań stanowiskowych obliczenia numeryczne. Obliczenia te są szczególnym typem analizy numerycznej, gdyż wymagają symulacji nagrzewania koła a następnie jego chłodzenia i odczytania wartości naprężeń resztkowych w kole powstałych w wyniku przekroczenia granicy sprężystości w tarczy koła.

Warunki obciążeń dla badania odporności termomechanicznej dobiera się zgodnie z normą PN-EN 13979-1 oraz 2006/861/WE wraz z uwzględnieniem zmian wprowadzonych decyzją 2009/107/WE, w której zmniejszono z 80 do $60 \mathrm{~km} / \mathrm{h}$ prędkość hamowania. Na tej podstawie przeprowadza się symulację hamowania $\mathrm{z}$ mocą $50 \mathrm{~kW}$ w czasie 45 minut $(2700$ s) wynikającą z prędkości $60 \mathrm{~km} / \mathrm{h}$ a następnie badane koło kolejowe chłodzi się do temperatury otoczenia w czasie kolejnych 45 minut.

Przedstawione badania przeprowadza się zarówno dla koła o średnicy nominalnej Ø920 mm, jak i koła o maksymalnym zużyciu eksploatacyjnym Ø854 mm.

\section{Przykładowa analiza numeryczna koła kole- jowego}

Analizując warunki eksploatacji kół kolejowych można stwierdzić, że największe obciążenia kół generowane są podczas hamowania. Największy udział z tych obciążeń stanowią obciążenia termiczne wynikające $\mathrm{z}$ generowanego $\mathrm{w}$ czasie tarcia strumienia ciepła.

Należy w tym miejscu zaznaczyć, iż z badań własnych autorów wynika, że największe naprężenia a w zasadzie odkształcenia $\mathrm{w}$ kole kolejowym w czasie całej jego eksploatacji występują w strefie styku koła z szyną podczas długotrwałego hamowania.

Powstałe $\mathrm{w}$ ten sposób zmiany pól temperatur powodują odkształcenia materiału koła proporcjonalne do współczynnika rozszerzalności termicznej stali ER7. Jednocześnie wskutek zmian temperatury koła zmieniają się jego własności fizyczne. W przeprowadzonej analizie numerycznej wzięto pod uwagę następujące nieliniowości modelu numerycznego:

- nieliniowa geometria modelu;

- elementy skończone o nieliniowej funkcji kształtu - elementy heksagonalne 20 węzłowe;

- wartości modułu Younga, współczynnika Poissona, współczynniki rozszerzalności cieplnej, gęstości właściwej, ciepła właściwego oraz przewodności cieplnej zostały uwarunkowane od temperatury materiału koła $\mathrm{w}$ zakresie $0 \div 740{ }^{\circ} \mathrm{C}$;
- współczynnik konwekcji został przydzielony zależnie od stref koła wg badań własnych autorów [2];

- materiał koła ER7 zamodelowano w taki sposób aby umożliwić zjawiska po przekroczeniu granicy sprężystości Re (umożliwiono uzyskanie odkształceń plastycznych materiału koła po przekroczeniu naprężeń dopuszczalnych;

- analizy sprzężone termiczno - mechaniczne prowadzone były dla kilkuset podkroków obliczeniowych $\mathrm{z}$ uwzględnieniem zmian zjawisk termicznych $\mathrm{w}$ czasie (transient) oraz jednoczesnym uwzględnieniem zmian strukturalnych w tym uplastycznienia materiału.

$\mathrm{W}$ trakcie analizy zadano równomierne wnikanie strumienia ciepła w koło na całym jego obwodzie o szerokości wstawki hamulcowej. Wartości konwekcji oraz własności materiałowe wprowadzono zgodnie $\mathrm{z}$ wcześniejszymi wynikami prac badawczych autorów [2]. W trakcie symulacji uwzględniono obciążenia termiczne wynikające z prędkości jazdy $60 \mathrm{~km} / \mathrm{h}$ i mocy hamowania $50 \mathrm{~kW}$ w czasie 2700 sekund (45 minut). W dalszym czasie symulacji tj. $2700-5400 \mathrm{~s}$ prowadzono chłodzenie do temperatury otoczenia $\mathrm{w}$ celu zobrazowania naprężeń resztkowych wynikających z uplastycznienia materiału koła w trakcie nadmiernych obciążeń termicznych. Analiza naprężeń w kołach kolejowych wynikających $\mathrm{z}$ obciążeń termicznych została przeprowadzona nieliniowo. Wszystkie własności materiałowe zadeklarowano, jako zależne od temperatury.

Model numeryczny wykonano, jako obrotowo symetryczny na bazie modelu wykonanego $\mathrm{w}$ programie CATIA v5 - rys. 1.

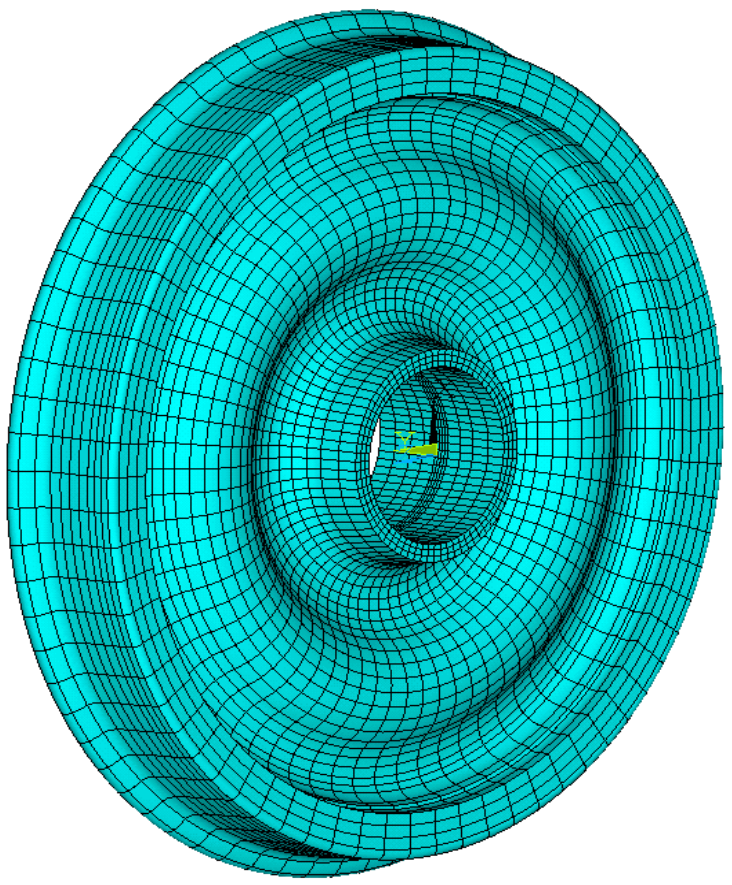

Rys. 1. Siatka elementów skończonych badanego koła kolejowego o średnicy nominalnej Ø $920 \mathrm{~mm}$ 
Dyskretyzację modelu CAD siatką elementów skończonych przeprowadzono $\mathrm{w}$ taki sposób aby uzyskać elementy ośmiościenne, które pozwalają na bardzo dobre odwzorowanie geometrii przy niewielkiej liczebności stopni swobody modelu. Dlatego też, model numeryczny wykonano $\mathrm{z}$ wykorzystaniem blisko 13 tysięcy heksagonalnych dwudziestowęzłowych elementów skończonych o nieliniowej funkcji kształtu. W wyniku analizy numerycznej MES uzyskano rozkład przemieszczeń sumarycznych, temperatur, stref uplastycznienia materiału oraz rozkład naprężeń redukowanych HMH dla czasu z zakresu 0$5400 \mathrm{~s}$ w tym dla czasu $2700 \mathrm{~s}$ odpowiadającemu końcowi hamowania koła (nagrzewania) oraz czasu 5400 s odpowiadającemu stanowi wychłodzenia koła do temperatury zbliżonej do temperatury otoczenia.

Ze względu na wymagania Dziennika Urzędowego Unii Europejskiej 2006/861/WE z uwzględnieniem zmian wprowadzonych decyzją 2009/107/WE analizie numerycznej poddano wymagania zawarte $\mathrm{w}$ punkcie 1.1.4 "Ocena zgodności termomechanicznej" ww. dokumentu, w którym stwierdza się, że analiza numeryczna prowadzona jest celem określenia najbardziej niekorzystnego przypadku pod względem geometrii koła na jego zachowanie termomechaniczne i stanowi podstawę do badań doświadczalnych określonych $\mathrm{w}$ trójetapowej procedurze oceny kół 1.1.4.1.

Ze względu na fakt, że przedstawione w normie PN-EN 13979-1 oraz Dzienniku Urzędowym Unii Europejskiej 2006/861/WE kryteria oceny dotyczą badań stanowiskowych, przedstawione wyniki badań numerycznych nie mogą stanowić kryterium oceny konstrukcji kół kolejowych i są prowadzone w celu określenia krytycznych z punktu widzenia wytrzymałości koła warunków badań doświadczalnych (geometria, miejsca pomiaru, czas pomiaru w zakresie wymagań TSI).

\section{Analiza wymagań 1.1.4.2.2 "Kryteria decy- zyjne" 2006/861/WE dla badań stanowisko- wych - dla kola nowego}

\section{Wymaganie 1 TSI (dla badań stanowiskowych):}

\section{Dla koła nowego:}

1. Maksymalne boczne przemieszczenia podczas hamowania $+3 /-1 \mathrm{~mm}$

Przesunięcie boczne uważa się za dodatnie, jeżeli odległość pomiędzy zewnętrznymi bokami obrzeża wzrasta.

Wyniki przeprowadzonej analizy numerycznej rys. 2:

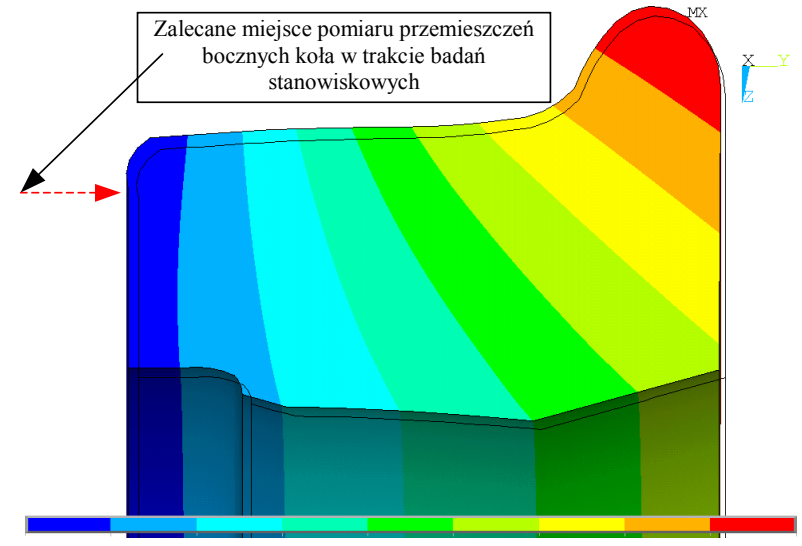

Rys. 2. Rozkład przemieszczeń sumarycznych w kierunku osiowym (oś y) dla badanego koła kolejowego o średnicy nominalnej Ø $920 \mathrm{~mm} \mathrm{w}$ czasie $2700 \mathrm{~s}$

\section{Ocena:}

$\mathrm{Na}$ podstawie przeprowadzonych badań numerycznych przykładowego koła kolejowego symulujących warunki badań stanowiskowych można stwierdzić, że uzyskane przemieszczenie $2,45 \mathrm{~mm}$ nie przekracza wartości dopuszczalnej $3 \mathrm{~mm}$. Uzyskane wyniki symulacji numerycznych pozwalają na określenie miejsc pomiaru przemieszczeń badanego koła kolejowego podczas badań stanowiskowych. Dlatego też na podstawie obliczeń numerycznych proponuje się miejsce pomiaru przemieszczeń bocznych (osiowych) wg rys. 2.

\section{Wymaganie 2 TSI (dla badań stanowiskowych):}

Dla koła nowego:

Naprężenia resztkowe wieńca po ochłodzeniu:

$-\sigma_{\mathrm{rn}} \leq+\Sigma_{\mathrm{r}} \mathrm{N} / \mathrm{mm}^{2}$, jako średnia $\mathrm{z}$ trzech pomiarów;

$-\sigma_{\text {in }} \leq+\left(\Sigma_{\mathrm{r}}+50\right) \mathrm{N} / \mathrm{mm}^{2}$, dla każdego z pomiarów;

Dla gatunku ER7 zgodnego $\mathrm{z}$ normą $\Sigma_{\mathrm{r}}=200$ $\mathrm{N} / \mathrm{mm}^{2}$.

Wyniki analizy numerycznej przykładowego koła klejowego - rys. 3:

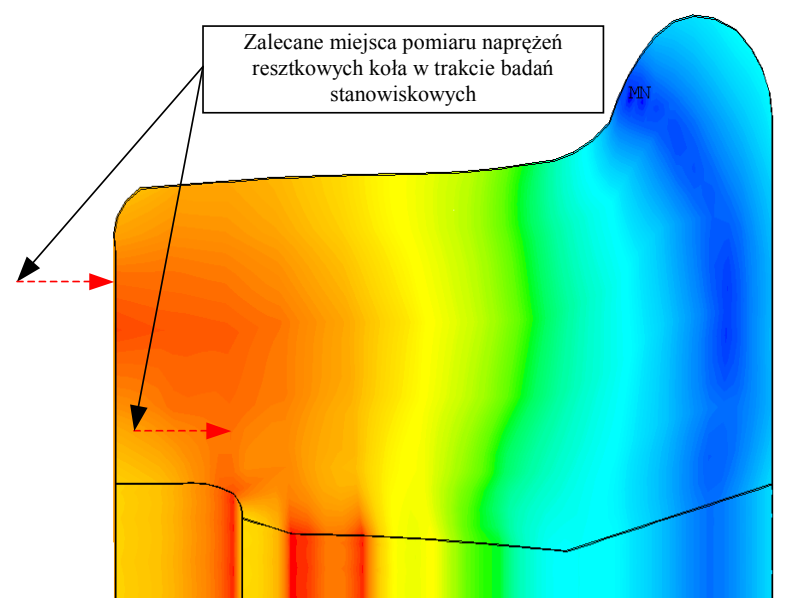

Rys. 3. Rozkład naprężeń resztkowych wieńca przykładowego koła kolejowego o średnicy nominalnej Ø $920 \mathrm{~mm}$ po ochłodzeniu - $5400 \mathrm{~s}$ - zalecane miejsca pomiaru 


\section{Ocena:}

$\mathrm{Na}$ podstawie przeprowadzonych badań numerycznych symulujących warunki badań stanowiskowych można stwierdzić, że uzyskane maksymalne wartości naprężeń resztkowych w wieńcu koła wynikających z hamowania długotrwałego (45 minut) o mocy $50 \mathrm{~kW}$ a następnie chłodzenia do temperatury zbliżonej do temperatury otoczenia wyniosły $24 \mathrm{MPa}$ tym samym nie przekroczono wartości dopuszczalnej $250 \mathrm{MPa}$. Jednocześnie proponuje się miejsce pomiaru naprężeń resztkowych w czasie badań stanowiskowych wg rys. 3 .

\section{Uwaga:}

Przedstawione $\mathrm{w}$ dokumencie kryterium naprężeń resztkowych pomija zjawiska zachodzące w tarczy koła, w której maksymalne naprężenia resztkowe były większe niż w wieńcu koła i wyniosły blisko $100 \mathrm{MPa}$ - rys. 4.

Fakt ten jest szczególnie istotny, gdyż tego typu zjawisko może występować w większości konstrukcji kół kolejowych a uzyskane wartości naprężeń mogą być większe od dopuszczalnych i w efekcie powodować pękanie zmęczeniowe w trakcie długotrwałej eksploatacji. Dlatego też, należy domniemywać, że przedstawione niedopatrzenie będzie skorygowane $\mathrm{w}$ następnej rewizji wspomnianego TSI.

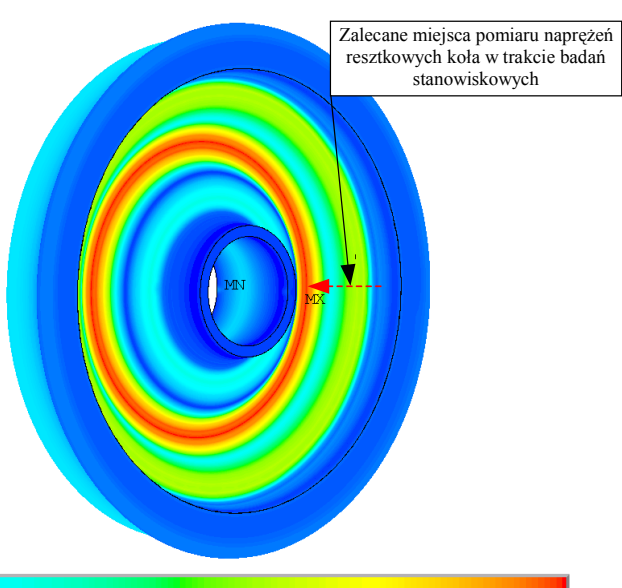

Rys. 4. Rozkład naprężeń resztkowych w przykładowym kole kolejowym o średnicy nominalnej Ø? $920 \mathrm{~mm}$ po ochłodzeniu $5400 \mathrm{~s}$ - zalecane miejsca pomiaru

Wymaganie 3 TSI (dla badań stanowiskowych):

Dla koła nowego:

1. Maksymalne boczne przemieszczenia wieńca po ochłodzeniu $+1,5 /-0,5 \mathrm{~mm}$

Przesunięcie boczne uważa się za dodatnie, jeżeli odległość pomiędzy zewnętrznymi bokami obrzeża wzrasta.

Wyniki analizy numerycznej - rys. 6:

\section{Ocena:}

$\mathrm{Na}$ podstawie przeprowadzonych badań numerycznych symulujących warunki badań stanowiskowych można stwierdzić, że uzyskane przemieszczenie $0,19 \mathrm{~mm}$ nie przekracza wartości dopuszczalnej
1,5 mm. Jednocześnie proponuje się miejsce pomiaru przemieszczeń bocznych (osiowych) wg rys. 6 .

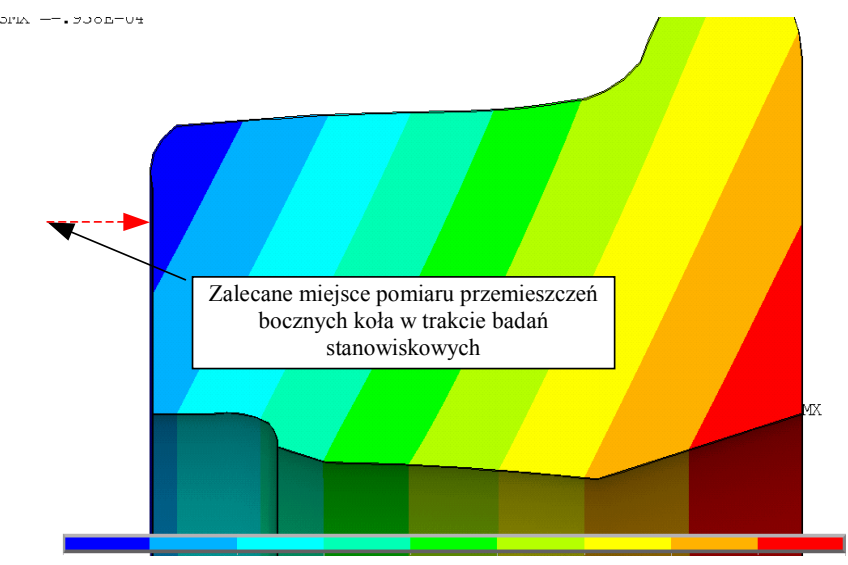

Rys. 6. Rozkład przemieszczeń sumarycznych w kierunku osiowym (oś y) dla przykładowego koła kolejowego o średnicy nominalnej Ø $920 \mathrm{~mm}$ w czasie $5400 \mathrm{~s}$

5. Analiza wymagań 1.1.4.2.2 "Kryteria decyzyjne" 2006/861/WE dla badań stanowiskowych - dla koła zużytego

Dla koła zużytego tj. o średnicy tocznej Ø 854 $\mathrm{mm}$ przeprowadza się analizę numeryczną o identycznych obciążeniach termicznych jak dla koła nowego. Ten etap analizy jest dla większości konstrukcji kół kolejowych momentem decydującym, gdyż koło kolejowe o maksymalnym zużyciu jest szczególnie podatne na obciążenia termiczne w wyniku znacznej redukcji masy $\mathrm{w}$ strefie narażonej na strumień ciepła wynikający z hamowania klockami hamulcowymi.

\section{Wymaganie 1 TSI (dla badań stanowiskowych) -} jest identyczne jak dla koła nowego

\section{Wyniki analizy numerycznej - rys. 7:}

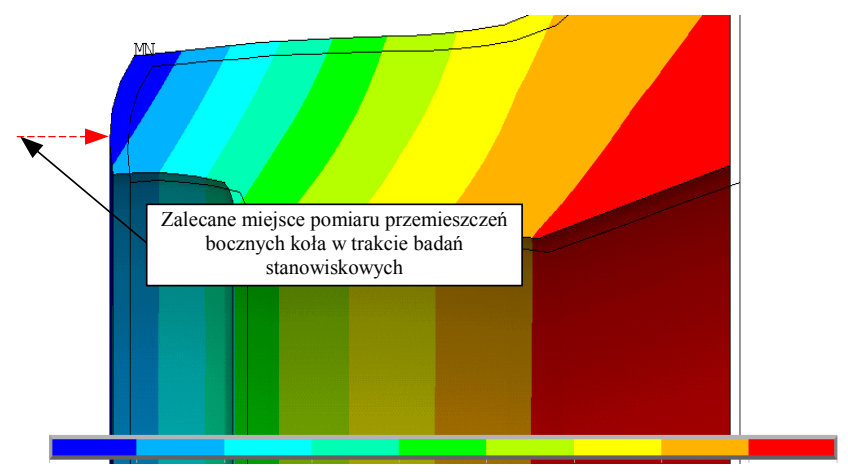

Rys. 7. Rozkład przemieszczeń sumarycznych w kierunku osiowym (oś y) dla przykładowego koła kolejowego o średnicy nominalnej Ø $854 \mathrm{~mm}$ w czasie $2700 \mathrm{~s}$

\section{Wymaganie 2 TSI (dla badań stanowiskowych):}

\section{Dla koła zużytego:}


Naprężenia resztkowe $\mathrm{w}$ wieńca ${ }^{1}$ po ochłodzeniu: - $\sigma_{\mathrm{rn}} \leq+\left(\Sigma_{\mathrm{r}}+75\right) \mathrm{N} / \mathrm{mm}^{2}$, jako średnia $\mathrm{z}$ trzech pomiarów;

$-\sigma_{\text {in }} \leq+\left(\Sigma_{\mathrm{r}}+100\right) \mathrm{N} / \mathrm{mm}^{2}$, dla każdego z pomiarów; Dla gatunku ER7 zgodnego $\mathrm{z}$ normą $\Sigma_{\mathrm{r}}=200$ $\mathrm{N} / \mathrm{mm}^{2}$.

Wyniki analizy numerycznej - rys. 8:

\section{Ocena:}

Również dla koła zużytego przedstawione w dokumencie kryterium naprężeń resztkowych pomija zjawiska zachodzace w tarczy koła, w której dla większości konstrukcji uzyskują większe wartości naprężeń resztkowych w tarczy niż we wieńcu koła rys. 9.

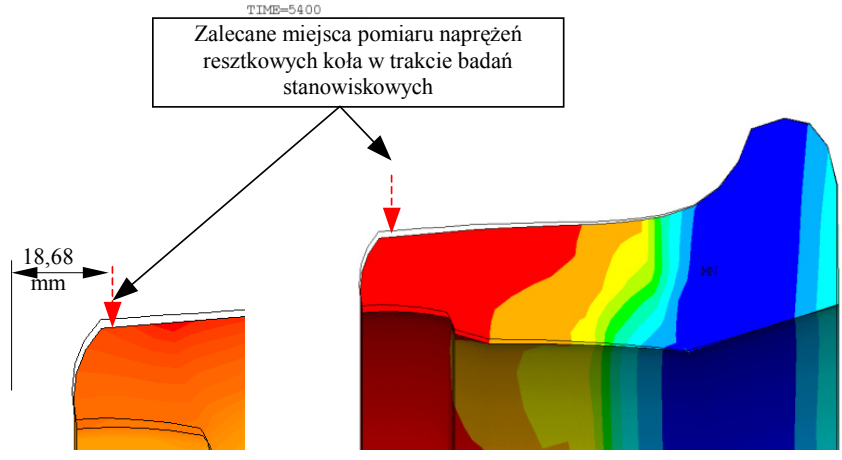

Rys. 8. Rozkład naprężeń resztkowych we wieńcu koła kolejowego o średnicy nominalnej Ø $854 \mathrm{~mm}$ po ochłodzeniu - 5400 $\mathrm{s}$ - zalecane miejsca pomiaru

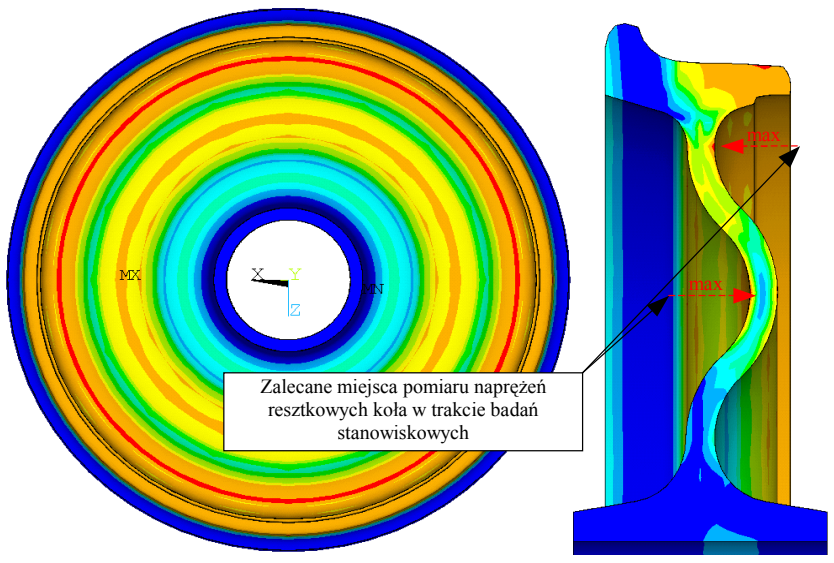

Rys. 9. Rozkład naprężeń resztkowych w przykładowym kole kolejowym o średnicy nominalnej Ø $854 \mathrm{~mm}$ po ochłodzeniu $5400 \mathrm{~s}$ - zalecane miejsca pomiaru
Uzyskane wyniki badań numerycznych oraz miejsca pomiaru przedstawiono na rysunkach wymienionych w tabeli 1.

Podobne zestawienie jak w tab. 1 wykonuje się dla koła zużytego. Analizowane przykładowe koło kolejowe o średnicy nominalnej $\phi 920 \mathrm{~mm}$ uzyskało wyniki zgodne $\mathrm{z}$ wymaganiami normy PN-EN 13979-1 oraz Dziennika Urzędowego Unii Europejskiej 2006/861/WE z uwzględnieniem zmian wprowadzonych decyzją 2009/107/WE we wszystkich trzech kryteriach pierwszego etapu badań (według punktu 1.1.4.1). Oznacza to, że po poddaniu koła ekstremalnym obciążeniom termicznym wynikającym z hamowania o mocy $50 \mathrm{~kW}$ w czasie $2700 \mathrm{~s}$, a następnie chłodzeniu do temperatury otoczenia uzyskane wartości przemieszczeń osiowych oraz naprężenia resztkowe wieńca koła nie przekroczyły wartości dopuszczalnych. Jednocześnie po przeprowadzeniu badań numerycznych zaleca się prowadzenie pomiarów przemieszczeń sumarycznych i naprężeń według schematu pokazanego na powyższych rysunkach. Należy zaznaczyć, że zarówno dla koła o średnicy tocznej $\phi 920 \mathrm{~mm}$ jak i dla $\phi 854 \mathrm{~mm}$ największe wartości naprężeń resztkowych zaobserwowano w tarczy koła, dlatego też, na rysunkach powyżej przedstawiono miejsca występujących maksimów naprężeń. W badanym kole kolejowym o średnicy odpowiadającej maksymalnemu zużyciu stwierdzono odkształcenia plastyczne w obszarach pokazanych na rys. 9. Jednocześnie stwierdzono również szczególnie dużą wartość przemieszczeń promieniowych na koń$\mathrm{cu}$ zewnętrznej części powierzchni tocznej koła. Przemieszczenia te wynikają z odkształceń plastycznych strefy materiału łączącej wieniec i tarczę koła kolejowego zachodzących w czasie chłodzenia i powodują zmianę geometrii układu koło kolejowe szyna po hamowaniu w przedstawionych wcześniej warunkach a następnie chłodzeniu koła do temperatury otoczenia.
Tabela 1

Zestawienie wyników analizy przykladowego koła kolejowego według wymagań normy PN-EN 13979-1 oraz Dz.U. 2006/861/WE wraz z decyzją 2009/107/WE

\begin{tabular}{|c|c|c|c|}
\hline $\begin{array}{c}\text { Wymagania } \\
\text { PN-EN 13979 }\end{array}$ & $\begin{array}{c}\text { Wymaganie 1 } \\
\text { (podczas hamowania) }\end{array}$ & $\begin{array}{c}\text { Wymaganie 2 } \\
\text { (po ochłodzeniu) }\end{array}$ & $\begin{array}{c}\text { Wymaganie 3 } \\
\text { (po ochłodzeniu) }\end{array}$ \\
\hline $\begin{array}{c}\text { Kryterium dla } \\
\text { nowego koła }\end{array}$ & $\begin{array}{c}\text { Przemieszczenia wieńca } \\
\text { koła } \Delta U \in(-1 \div 3) \mathrm{mm}\end{array}$ & $\begin{array}{c}\text { Naprężenia wieńca koła } \\
\sigma_{\text {in }} \leq 250 \mathrm{MPa}\end{array}$ & $\begin{array}{c}\text { Przemieszczenia wieńca } \\
\text { koła } \Delta U \in(-0,5 \div 1,5) \mathrm{mm}\end{array}$ \\
\hline Uzyskana wartość & $2,45 \mathrm{~mm}$ & $\begin{array}{c}24 \mathrm{MPa} \\
(100 \mathrm{MPa} \text { tarczy) }\end{array}$ & $0,19 \mathrm{~mm}$ \\
\hline Miejsce pomiaru & rys. 2 & rys. 3 & rys. 6 \\
\hline
\end{tabular}




\section{Wnioski}

$\mathrm{W}$ artykule przedstawiono przykładową procedure badań numerycznych kół kolejowych zgodnie z wymaganiami TSI dla określenia naprężeń resztkowych w kole kolejowym. Wskazano również na te elementy, które stanowią niedopatrzenie wymagań TSI w zakresie kryteriów dopuszczeniowych a mają istotne znaczenie dla bezpieczeństwa eksploatowanych kół kolejowych. W rozpatrywanym przykładowym kole kolejowym zarejestrowano przekroczenie wartości dopuszczalnych naprężeń oraz odkształceń wynikających z hamowania długotrwałego a następnie chłodzenia w wyniku którego wieniec koła odkształcił się trwale o $1,9 \mathrm{~mm}$.

\section{Literatura}

[1] Dziennik Urzędowy Unii Europejskiej 2006/861/WE Decyzja Komisji z dnia 28 lipca 2006 r. dotyczaca technicznej specyfikacji dla interoperacyjności odnoszacej sie do podsystemu ,tabor kolejowy - wagony towarowe" transeuropejskiego systemu kolei konwencjonalnych, zwany potocznie TSI "Tabor - wagony towarowe" - $2006 r$;

[2] Sitarz M., Mańka A.: Badania aerodynamiczne lokomotyw a termodynamika uktadu koto kolejowe - klocek hamulcowy, I Ogólnopolska konferencja naukowo techniczna Modernizacja taboru szynowego, Tarnowskie Góry 2012;

[3] Sitarz M., Mańka A., i inni. Sprawozdanie roczne pracy badawczej N509 19784, $\mathrm{nr}$ PBU-11/RT4/2011 pt.: „Optymalizacja konstrukcji ukladu hamulcowego pojazdu szynowego z uwzględnieniem sprzężenia zjawisk mechanicznych, termicznych i aerodynamicznych", luty $2012 r$

[4] Mańka A. Sitarz M. "Analiza zjawisk mechanicznych $i$ termicznych zachodzacych w ukladzie kolo kolejowe klocek hamulcowy" - Monografia, Wydawnictwo - Pracownia Komputerowa Jacka Skalmierskiego, Katowice 2011 rok. 